\title{
The Relationship Between Corporate Governance Characteristics and Credit Exposure in Banks Implications for Financial Regulation
}

\author{
Rose, Caspar
}

Document Version

Accepted author manuscript

Published in:

European Journal of Law and Economics

DOI:

$10.1007 / \mathrm{s} 10657-016-9535-2$

Publication date:

2017

Citation for published version (APA):

Rose, C. (2017). The Relationship Between Corporate Governance Characteristics and Credit Exposure in Banks: Implications for Financial Regulation. European Journal of Law and Economics, 43(1), 167-194. https://doi.org/10.1007/s10657-016-9535-2

Link to publication in CBS Research Portal

\section{General rights}

Copyright and moral rights for the publications made accessible in the public portal are retained by the authors and/or other copyright owners and it is a condition of accessing publications that users recognise and abide by the legal requirements associated with these rights.

\section{Take down policy}

If you believe that this document breaches copyright please contact us (research.lib@cbs.dk) providing details, and we will remove access to the work immediately and investigate your claim. 


\section{The Relationship between Corporate Governance Characteristics and Credit Exposure in Banks: Implications for Financial Regulation}

\section{Caspar Rose}

Journal article (Post print version)

CITE: The Relationship Between Corporate Governance Characteristics and Credit Exposure in Banks: Implications for Financial Regulation. / Rose, Caspar. In: European Journal of Law and Economics, Vol. 43, No. 1, 02.2017, p. 167-194.

The final publication is available at Springer via http://dx.doi.org/10.1007/s10657-016-9535-2

Uploaded to Research@CBS: May २०17 
The relationship between corporate governance characteristics and credit risk exposure in banks

- implications for financial regulation

February 11. 2016

By

Caspar Rose

Professor, Ph.D.

Copenhagen Business School

Department of International Economics and Management

Center for Corporate Governance

Porcelænshaven 24A, 1. Sal

2000 Frederiksberg

E-mail: car.int@cbs.dk

Phone: +45 38153037

Mobile: +4520342652 


\begin{abstract}
This article analyses board structures in listed Danish banks in the years prior to the financial crisis by exploring the relationship between corporate governance characteristics and credit risk exposure. The article presents a novel approach as it relies on a newly developed risk metric entitled the "Supervision Diamond" introduced by the Danish FSA, which "external" board directors must address. It contains five thresholds for measuring a bank's exposure to credit risks i.e. the proportion of large customers, lending growth, the ratio of lending/deposits, liquidity buffer and the proportion of real estate loans.
\end{abstract}

By employing quantitative governance variables the article finds that increased executive director remuneration is associated with increased credit risk posed by the bank's borrowers. On the other hand, increasing the number of executive/ "inside" directors is associated with a lower credit risk exposure. It is argued that more "inside" directors on the executive board constitutes a stronger "checks and balance" system. The article also documents that the probability of obtaining state capital from the Danish credit bailout package is negatively related to larger boards as well as higher executive director remuneration.

The policy implication is that financial authorities should be increasingly aware of insufficient corporate governance characteristics in order to prevent excessive credit risk exposure. Moreover, the article provides important insights on which corporate governance variables have a significant impact on a bank's credit risk exposure. This knowledge is valuable for financial authorities/policy makers considering future regulatory initiatives and how they should administer bank monitoring.

Keywords: Corporate governance; board composition; financial regulation; credit risk exposure and banking

JEL Classification: G21, G30, K22, K23 and L51 


\section{Introduction}

There is no doubt that the global financial crisis was triggered by a series of independent causes such as low interest rates, high leverage, misallocation of investment, unsatisfactory rating practices, insufficient supervision by financial regulators etc. However, it also seems evident that insufficient corporate governance structures played a vital role in the emergence of the financial crisis, which resulted in excessive credit risk taking in banks. Academic literature has focused primarily on the role of corporate governance in financial institutions. This article fills the gap in the literatureby relying on a relatively simple measure of a bank's credit risk exposure introduced by the Danish FSA, to study the relationship between a large number of corporate governance variables and the degree of credit risk exposure.

Denmark was seriously impacted by the financial crisis that caused a tremendous shock to the existing financial system, which resulted in a vast amount of new financial legislation. Moreover, a dozen Danish banks have gone bankrupt which was mainly caused by the burst of the Danish real estate bubble. In fact, Denmark is one of few countries in which not only shareholders, but also ordinary depositors have lost their savings. It is a widespread belief that the Danish banking system's collapse is a result of a lack of control by shareholders as well as financial authorities, and in particular, inefficient monitoring by the supervisory boards of executive management. There is also evidence that remuneration incentives at the executive level were inappropriate. The reason was that the performance of CEOs was partly evaluated based on the earnings they generated relative to their peers. Therefore, they may have taken excessive risks in order to boost various observable measures of performance, see Diamond and Rajan (2009).

As was the case in other countries, the Danish government was forced to take action in order to safeguard the entire banking system by providing large sums of capital injections to the banks. These bailout initiatives took the form of four subsequent "Bank Packages" that also contained massive capital injections to strengthen the banks solvency by providing state guarantees. 
Furthermore, the government provided incentives to stabilize banks in order to stimulate the acquisition of unhealthy banks by voluntary mergers.

Several Western countries have also introduced bailout packages as well as a vast amount of new financial regulation in the aftermath of the financial crisis. Bailout packages, in which the largest were introduced in the US and the UK, were designed to safeguard the financial stability of banks. The Obama administration introduced several acts that contained new compliance standards, but also created new institutions in order to leverage the many new rules. Similar initiatives have been introduced by the EU. The new MiFID II (2014/65/EC) is expected to be applicable in the beginning of January 2017. The objective is to strengthen investor protection by providing increased transparency for investors, including a prohibition against misleading marketing communication (article 24). For example, it is now stated that investment firms must ensure that financial instruments are offered or recommended only when this is in the interest of the client (article 25).

In connection with European Capital Requirements Directive (CRD 4), the EU has formulated a number of new hard laws that address issues such as remuneration, reporting, board diversity and board composition. Specifically, there are limits on the number of external board positions an internal director may hold in other companies, new rules regarding risk and nomination committees as well as limits on the proportion of bonus or variable pay relative to fixed pay. These initiatives are hard laws, reflecting that regulators and policy makers are not entirely relying on soft laws to regulate these important issues. The regulation is quite comprehensive, but it states some overall principles i.e. investment firms shall act honestly, fairly and professionally. This means that all information, including marketing communications addressed from the investment firm to clients or potential clients shall be fair, clear and not misleading (article 19). Sadly enough, the financial crisis has revealed that not all financial institutions followed these sound principles. 
To illustrate, some Danish bank customers obtained loans that in retrospect should never have been granted or marketed. Thus, in one case a Danish bank offered loans with the purpose of buying back the bank's own shares.

Following the crisis, the Danish FSA was granted several new regulatory tools in order to strengthen its control over the financial soundness of banks and to regain investors' confidence in the Danish financial system. The fundamental question is therefore, if investors, shareholders, regulators, auditors etc. could have foreseen that a number of banks accepted too much credit risk. In other words, this article is concerned with the analysis of credit risk posed by the bank's borrowers.

The Danish FSA was criticized following the financial crisis as several commentators argued that the FSA did not have enough regulatory power. A number of commentators asked themselves; why did the authorities not to a larger extent intervene in the banking sector prior to the crisis requiring improved corporate governance structures as well as restrictions on credit risks such as requiring larger loan impairments? It should be recognized that during the booming years, the yearly staff turnover in the Danish FSA was over 25 percent. This meant that crucial human capital was lost as employees were offered jobs in the financial sector where they earned considerably higher salaries. In other words, there was both an apparent lack of will and ability to confront the banks with stricter credit requirements and stronger corporate governance mechanisms. However, this situation has changed since the crisis due to the fact that the FSA has received additional resources from the government.

The FSA has also been empowered with a right to lay off members of the supervisory board in financial institutions provided that the board member does not have the sufficient experience and skills to perform his/her entrusted job. 
This new legal tool is supposed to deter incompetent persons in the financial sector from accepting excessive risk taking. The FSA has also been granted an authority to impose fines without a court ruling, in the case that a financial institution acknowledges to have violated the banking regulation. In addition, the FSA now publishes on its website the results of its unannounced inspections of Danish banks including its important recommendations to the supervisory board.

Furthermore, the FSA has issued several new binding rules. The overall aim is to professionalize the supervisory board. As a consequence, supervisory board members must now be involved in much more detail about a bank's credit risks as well as its overall risk exposure. All banks must formulate a clear policy for its credit risk which should serve as guidance for the bank's credit operations. Restrictions on executive management's performance dependent wages have also been put in place hence the authorities are taking over more control from the bank's owners, as the shareholders were in several situations unable to challenge executive management's ambitions of high growth.

Despite the fact that the FSA has received several new legal initiatives as well as substantially more employees, almost nothing has changed in the corporate governance structure of Danish banks. Apart from a few individuals who have been sued in court for damages in some of the banks where the governance failure was extensive, nothing else has changed in the corporate governance structure of Danish banks. To illustrate, there have not been any material replacements in the supervisory boards which would provide room for new qualified board members.

This article is organized as follows. In the next section (section 2), a literature review is presented. Section 3 develops a number of relevant hypotheses. The data and methodology are outlined in section 4. Section 5 contains a description of Danish banks credit risk exposure. Their corporate governance characteristics are presented in section 6 . This is followed by section 7 , which contains the regression results. Section 8 offers an analysis of the Danish credit bailout package in relation to corporate governance. The article ends with a conclusion in section 9. 


\section{Literature}

In the following section, some of the key literature contributions will be discussed and outlined. Carolillo et al (2013) conduct an interesting analysis of the financial crisis based on organizational perspectives combining political and new institutionalism. They discuss the largest banks in the US finding evidence of high financial leverage as well as documenting that from the 1990's to the mid 2000's, the largest US banks enabled their shareholders and managers to experience spectacular gains, which partly was due to excessive risk taking.

In chronological order the authors document how deregulation favored the creation of the subprime mortgage market. Their main argument is that the recent financial crisis can be seen as the progressive disruption of the institutional framework, which is the equilibrium that ruled the Great Moderation period, due to two complementary although antagonist processes: action and institutionalization.

Grove et al. (2011) also study the US banking sector, but rely on a different methodology. They conduct an extensive study where they look at 32 different governance factors, which they relate to two performance measures i.e. ROA and Alfa (excess stock return). Their sample covers the period from 2005-2008 and includes 236 US public commercial banks. The authors find support for a negative relationship between leverage/loan quality and financial performance on loan quality?. They also study executive pay, which they find is positively associated with financial performance, but on the other hand they find a negative relationship with loan quality in the long run.

Ingley et al (2010) discuss the financial crisis from the perspective of both shareholder and stakeholder involvement. The authors argue that traditional oriented boards need to address both types of stakeholders, as the financial crisis has shown that a narrow focus on shareholder value should be modified. Specifically, they conduct an interesting survey among boards in New Zealand. They find that considerably less than 20 percent of the respondents believed their board was strongly able to influence the company's risk exposure. 
The results regarding the influence on risk exposure were especially notable with regard to the higher levels of importance respondents attached to determining risk exposure.

Hideaki Sakawa et al. (2012) analyze incentive compensation in Japan when individual Japanese executive compensation data was made public for the largest firms in 2010. In Denmark, there are no mandatory disclosure requirements regarding total individual director remuneration. The authors show that bank ties do not serve as substitutes for incentive compensation, unlike in the 1990's in Japan, when they were effective in solving agency conflicts. 'Moreover, the authors find that the role of compensation is found to be more effective in firms with a higher degree of foreign ownership.

The boards in Danish banks are dominated by men. Female CEOs are extremely rare, which is puzzling, since Denmark has a strong reputation for treating the sexes equally in the labor market. Rost and Osterloh (2010) discuss various explanations, arguing that in an environment of high uncertainty, financial experts and men have a higher inclination to underestimate financial risks compared to non-financial experts and women. The authors show that banks with a higher percentage of financial experts within executive management teams perform better in stable environments, but are more negatively affected by the financial crisis. As a consequence, they argue that greater diversity in executive management should be introduced by the board of directors.

Aebi et al (2012) study whether risk management in relation to corporate governance plays an important role. Specifically, mechanisms such as the presence of a chief risk officer (CRO) in a bank's executive board and whether this person i.e. the CRO reports to the CEO or alternatively directly to the board of directors is associated with superior performance in banks during the financial crisis. The sample consists of 573 banks in North America and the performance measures are buy and hold as well as ROE. The authors find that standard corporate governance variables are mostly insignificantly or even negatively related to a bank's performance during the crisis. This is striking, as the authors include several relevant variables. 
However, more importantly, their results indicate that banks, in which the CRO reports directly to the board of "external" directors and not to the CEO exhibit significant and positive stock returns during the crisis. A possible explanation is that the CEO is not able to manipulate or to serve as an information filter device between the CRO and the board.

Board independence is important in order to effectively monitor daily executive management. Independent board members can speak more freely and ask the CEO about information, which a non-independent board member may find more difficult to undertake. There is research that suggests that increased independence may increase performance.

In a study by Yin-Hua Yeh et al. (2011) who rely on data from the largest 20 financial institutions from the G8 Countries, it is shown that performance is higher for financial institutions with more independent "external" directors who serve on different committees. Their sample only covers two years (2007-08), which must be regarded as rather extreme years. They study performance using ROA, ROE and stock return to analyze its effect on audit, compensation and nomination committees. The authors find a remarkable result, namely that the independence/performance relationship is more significant in financial institutions with excessive risk taking behavior.

Furthermore, there is some evidence that if board members occupy too many board positions in other firms this may reduce firm profitability. Fich and Shivdasani (2006) analyze the impact of board members' positions in other firms. They document that firms where a majority of outside directors occupy three or more board seats have significantly lower market to book ratios than firms in which the majority of outside directors hold fewer than three board seats. The sample consists of 3,366 observations covering 508 industrial firms in Forbes 500 over seven years. The authors document a negative relationship between market to book ratio and outside directors having several board positions, which is robust to a wide range of sensitivity tests. Thus, the negative relationship also holds when they use accounting performance measures. 
Board size is another issue that has been studied extensively; see e.g. Yermack (1996). A few studies examine board size in the financial sector. Surprisingly enough, Adams and Mehran (2012) find a positive relationship between performance, measured as Tobin's Q and board size. Aebi et al (2012) document a similar positive result focusing on buy and hold returns as well as Tobin's Q for a large sample of US banks. However, other studies show no significant relationship such as Erken et al (2012) who study bank performance during the crisis.

Managerial remuneration plays a central role in corporate governance where the aim is to align the interests of executive management with the shareholders relying on financial incentives. Moreover, there have been a number of incidents where executive management has manipulated grant dates (back dating) in order to extract a higher rent from the shareholders, see Viral et al (2000).

Such moral hazard problems must be addressed through adequate institutions, especially the legal system in order to provide shareholders with adequate investor protection. Bebchuck et al. (2011) study CEO pay slide i.e. the CEO remuneration proportion relative to the top five executives covering a large sample of US firms. The authors analyze the impact on performance (measured by Tobin's Q) on CEO slides using 12.011 firm/year observations from 1993-2004 covering 2015 companies and 3.256 CEOs. The authors find a significant negative statistical relationship when CEO pay includes all sort of benefits including stock options.

Fahlenbrach and Stulz (2011) investigate whether bank performance during the financial crisis is related to CEO incentives before the crisis. They find some evidence that banks with CEOs whose incentives were better aligned with the interests of shareholders performed worse and no evidence that they performed better. The authors discuss the pros and cons for CEO incentive compensation in banks. They argue that large holdings of equity by CEOs could deter risk taking that might be profitable for shareholders and avoid excessive leverage. Specifically, they illustrate that banks with a larger proportion of option compensation contracts and a larger fraction of compensation in cash bonuses for their CEOs did not perform worse than other banks during the crisis. 
According to Fahlenbrach and Stulz (2011), bank CEOs did not reduce their holdings of shares in anticipation of the crisis or during the crisis; hence they also suffered large wealth losses in the wake of the crisis.

It has been argued that concentrated ownership holding in a listed corporation enables an owner to better monitor the management, and to direct decisions toward initiatives that increase in firm value, see Shleifer and Vishny (2003). Concentrated ownership may therefore influence board composition, in which executive management does not engage in excessive risk taking. The relationship between ownership concentration and market value of European banks is analyzed in Busta et al. (2014).

The authors find on average a negative effect of ownership concentration on bank value measured as Tobin's Q. Their sample covers a long period (13 years) and shows that legal families or origin play a significant role in the non-linear relationship.

\section{Hypotheses}

The theoretical foundation of the main hypothesis builds on principal agent theory; see Grossman and Hart (1983). CEO's are by construction agents who are supposed to safeguard the interests of the principals i.e. shareholders. However, due to imperfect information, moral hazard problems exist, which may result in excessive credit risk taking in order to maximize the agents own utility. Corporate governance deals with the ways in which the interests between agents and principals can be aligned. This entails that knowledge about specific corporate variables which are related to moral hazard activities is important, especially when financial regulators are to consider reforms of the existing corporate governance regime.

Following the financial crisis, a large number of articles and books that deal with the governance structures in financial organizations have emerged, see e.g. Adams (2009). There is reason to believe that some governance structures proved insufficient in a number of large financial institutions. 
The key question is what kind of governance system could have prevented or at least reduced the negative impact of the financial crisis, as noted by Ahrens et al (2011). The authors argue that future academic work within corporate governance should focus on specific topics, such as the level of financial understanding among board members. The authors mention that scholars should concentrate the analysis to a higher extent on board competences and less e.g. on board independence.

There is strong evidence that the financial turmoil has revealed severe shortcomings in the risk management practices. Specifically, boards understanding of the inherent risks associated with complex securities such as CDOs as well as CDS' were in several cases insufficient, see Kirkpatrick (2009).

Recent history has shown that corporate governance was unable to safeguard against excessive credit risk exposure in a number of financial firms. Kirkpatrick (2009) mentions a specific number of weaknesses such as insufficient stress testing, ineffective information transmission due to silo approaches, lower prestige and the status of risk management staff compared to traders as well as the lack of attention to the warning signs of liquidity risks.

However, according to the author, the most severe problem was that incentive systems contained strong incentives to take excessive risks. Furthermore, it has been argued that board members in a number of financial institutions did not have sufficient competences, since a large proportion of board members lacked financial experience. The following hypotheses are about portfolio-level credit risks for which investor protection and mortgage loan standards are relevant. This leads to the following main hypothesis.

H1: Insufficient corporate governance structures are associated with higher credit risk exposure in banks

Insufficient governance structures are often characterized by having board members who lack expertise or don't have enough time to attend all of the board meetings. 
Moreover, there is a low proportion of independent board members and/or the chairman and the CEO are the same person. Incidentally, the latter is not allowed in Danish listed firms. Increased independence may in theory improve the control and monitoring of executive management, but independent board members have less knowledge about the company compared to nonindependent board members. Thus, in the Danish legal framework, where the supervisory board has to formulate the overall strategy, too much independence may hamper efficient strategy development. There are extremely few dependent board members in Danish banks, so from a statistical perspective it does not make sense to analyze this issue due to the lack of variation in the data regarding board independence. The following sub-hypotheses specify the main hypothesis in more detail - all in relation to Danish banks

H1:1: Larger boards increase the credit risk exposure

There is reason to believe that large boards are not in the interest of shareholders due to the inherent free rider problem. This is not only the case in non-financial firms, see Yermack (1998) but also in financial firms, see Aebi et al. (2012). When boards become too large, there is reason to believe that each board member may have less incentive to monitor executive management. To illustrate, according to the Walker Review, boards in financial firms were larger compared to nonfinancial firms. This is considered problematic because the; “ widely-held view that the overall effectiveness of the board, outside a quite narrow range, tends to vary inversely with its size" c.f. 9 in Walker (2009). On the other hand, one may argue that since financial firms are often more complex this requires more human capital at board level.

In addition, there is reason to believe that if board members have too many competing board commitments in other firms they may not have enough time to control and monitor excessive credit risk taking e.g. if a CEO or other executive managers engage in excessive credit risk taking.

H1:2: Increasing the number of board positions in other firms increases the credit risk exposure 
Furthermore, managerial incentive contracts are central governance instruments, but their impact is ambiguous. The question of whether higher managerial compensation, especially stock market incentive contracts benefit shareholders is contentious. Holmstrom (1979) argues that incentive contracts are necessary for aligning the interests between shareholders and executive management. In other words, such contracts serve as a substitution for monitoring. In addition, it is often argued that incentive contracts are necessary for motivating, maintaining as well as attracting highly skilled and talented CEO's.

\section{H1:3 Higher CEO compensation increases banks risk exposure}

Other scholars argue that powerful managers are able to negotiate favorable remuneration contracts due to weak boards, see Adams et al (2005). Besides rent seeking there has been a considerable public debate on managerial remuneration in financial institutions following the financial crisis.

It has been argued that remuneration in financial institutions fostered short term excessive risk taking. To illustrate, according to the Financial Times, Merrill Lynch allowed their CEO and Chairman to retire with a remuneration package of $160 \mathrm{~m}$ dollars following a company loss of 8 billion dollars. This moral hazard incident has been entitled "return to failure". As a consequence, policymakers in both the EU and the US have imposed limitations on the use of variable pay in financial institutions.

One may argue that increased board diversity may stimulate board quality as espoused by Veltrop et al (2012). The reason is that board members may not act as independent actors, but as representatives of stakeholder fractions. Moreover, the evidence on gender and its link to performance in non-financial firms, see e.g. Rose (2007).

Adams and Ferreira (2009) study a large US sample covering the period from 1996-2003. They find evidence that more diverse boards are more likely to hold CEOs accountable for poor stock price performance. The reason is that CEO turnover is more sensitive to stock return performance 
in firms with relatively more women on boards which suggests that gender-diverse boards facilitate more stringent monitoring. Two other studies focus on financial firms i.e. Muller-Kahle and Lewellyn (2011) and Berger et al (2012), but their results are contradictory.

\section{H1:4: Increasing board diversity results in decreased risk exposure}

The first bailout initiative in Denmark was passed October 10, 2008 at a time when the international financial crisis was at its worst. The purpose was to ensure the stability of the Danish financial system by strengthening public trust as well as among investors in the financial system. To this end, both the government and the banks provided two years of unlimited guarantees for all deposits.

The banks themselves paid a provision of 15 billion DKK and the state provided 20 billion DKK . Simultaneously, a newly created legal institution called "Finansiel Stabilitet" was founded to take over all of the liabilities from banks that were in financial distress.

These initiatives were followed by bailout package No. 2 also known as the "Credit package", which was passed by the Danish Parliament on February 3, 2009. The main purpose was to reduce the risk that financially viable banks and households could not get sufficient funding or credit from banks. The banking sector received a 75 billion DKK capital injection in the form of loans with an average interest rate of 10 percent.

In order for banks to exercise this credit option, the state required banks to meet a number of conditions such as a prohibition against stock options for top management in banks as well as a reduced tax deduction of 50 percent for salaries to its top management. In order to be eligible for state capital, it was also required that the solvency ratio was at least 8 percent. They key observation here is that no banks were forced to apply for funding, but it was an option granted by the state (and not for free). One might hypothesize that banks with more sound corporate governance structures would have a better chance and also a stronger incentive to apply for state funding. 
H2: The probability of not getting state capital from the Danish credit bailout package is influenced by corporate governance structures.

\section{Data and methodology}

The analysis relies on the "Supervision Diamond" as a proxy for the degree of credit risk exposure in Danish banks. In order to assist the supervisory boards to implement a sound strategy that avoids excessive risk taking, the Danish FSA has developed what it calls the "Supervision Diamond" which contains five thresholds that should not be violated. The five thresholds are the following:

- Aggregate sum of large bank customers $<125 \%$ of base capital

- Yearly lending growth $<20 \%$

- Funding ratio < 1,0 (approximately equal to the ratio between lending/deposits)

- Liquidity surplus $>50 \%$ (approximate to base capital)

- Credit exposure to the real estate market $<25 \%$ (to aggregate credit)

\section{Illustration of the Supervision Diamond. Source: The Danish FSA}

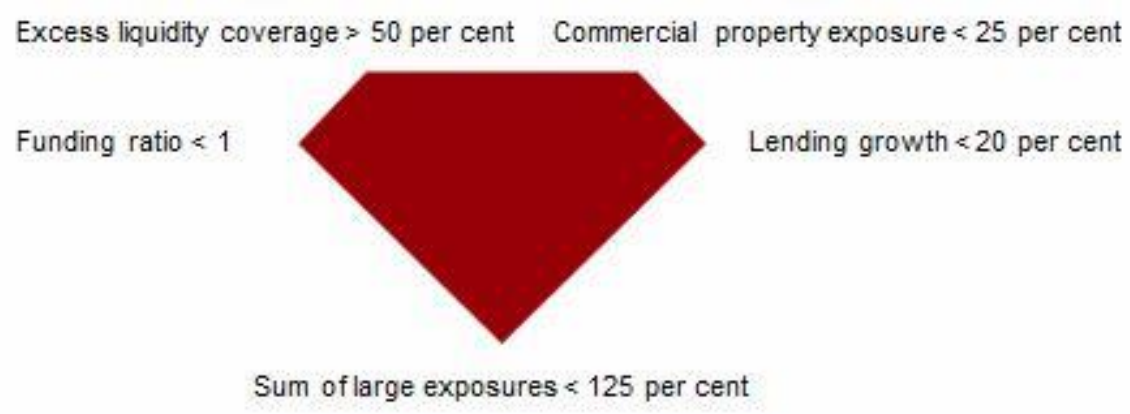

The objective is to avoid that a bank takes excessive risks and to formulate specific ratios that may serve as early warning signs. This article uses the aforementioned thresholds as dependent variables.

The data consists of key financial numbers for each year covering Danish listed banks during the period of 2005-09 for 35 banks. Descriptive statistics and correlation matrixes are shown in Figures 6-7. Data is collected from annual accounts and risk reports. 
Nordea Bank is also listed on the Copenhagen Stock Exchange, but since the bank follows the Swedish corporate governance recommendations/financial rules, Nordea has been excluded from the analysis. The sample only consists of listed banks, since it has not been possible to obtain the corporate governance data for unlisted banks. The financial variables in the article are taken from the annual accounts and are therefore defined according to the IFRS standards. To illustrate, lending growth does not include off-balance securitizations.

The following banks went into financial distress and have therefore been acquired by the institution "Finansiel Stabilitet": Ebh bank, Løkken Sparekasse, Gudme Raaschou Bank, Fionia Bank, Capinordic Bank, Eik Banki, Eik Bank Danmark, Amagerbanken, Fjordbank Mors (bank package III), Maxbank, samt Sparekassen Østjylland (bank package IV). Finansiel Stabilitet is the state-owned "settlement" company. It is a specially created bank, with the sole purpose of liquidating assets in a structured and organized manner. Unfortunately, it has not been possible to obtain reliable data about the majority of these banks in the analysis e.g. due to changes in accounting principles, which may potentially impact the analysis.

Amagerbanken and Max bank are both included in the analysis for all of the years, while it has not been possible to include? Roskilde Bank as the data only covers two years. Moreover, a number of banks have merged during the period, especially from 2008-09, which often led to changes in the articles of incorporation/accounting principles. A limited number of banks have been reluctant to provide relevant public information e.g. on the proportion of real estate loans. Moreover, a few a banks have not published comprehensive information concerning their corporate governance data. Regarding managerial remuneration, it was not possible to obtain complete information about the total value of $\mathrm{CEO}$ compensation for a minority of firms, especially regarding the value of option grants and pension rights.

The vast majority of Danish banks are not financial conglomerates but consist of local and regional banks with a focus on commercial banking. Nordea is an exception, but as noted previously, Nordea is not part of the sample. Only Danske Bank is a full financial conglomerate. 
The control variable Ln Assets seeks to control for size. The data on the banks corporate governance structures has been carefully and manually collected during a period of two years. The data sources consist of the annual accounts, the articles of incorporation, minutes of the general meetings as well as the banks homepages.

This article makes use of traditional panel regression methodology facilitating both a crosssectional a time dimension for each bank observation. The analysis builds on the following model:

$$
Y_{i t}=X_{i t} \beta+\mu_{i t}
$$

$Y_{i t}$ is the dependent variable (i.e. a threshold in the Supervision Diamante) observed for bank $i$ at time $t . X_{i t}$ is the time-variant regressor matrix consisting of independent variables, $\alpha_{i}$ is the unobserved time-invariant individual effect and $\mu_{i t}$ is the error term. Unlike $X_{i t}, \alpha_{i}$ cannot be observed. Common examples for time-invariant effects $\alpha_{i}$ are characteristics of individuals or historical and institutional factors of firms.

Unlike the random effect model where the unobserved $\alpha_{i}$ is independent of $X_{i t}$ for all $t=1, T$ the fixed effect model allows $\alpha_{i}$ to be correlated with the regressor matrix. The fixed effect model is widely used in similar studies combining both cross-sectional as well as the time dimension of the dataset. Cluster-robust standard errors have not been used in this article. Econometric theory states that if the effects are correlated with the explanatory variables, the fixed effects estimator is consistent and efficient but the random effects estimator is now inconsistent, see Johnston and DiNardo (1997) p.404. A Hausman test shows that the fixed effects estimator is preferred in this situation.

\section{Description of Danish Banks credit risk exposure}

Figure 1 shows key financial ratios in relation to the Supervision Diamond as an un-weighted average of all listed Danish banks. Prior to the crisis, the average yearly credit growth was quite high i.e. $16.28 \%$, but this number reflects very large deviations among the Danish banks. 
A few banks had annual credit growth rates of more than 40 percent, but the vast majority of banks had more modest growth rates.

\section{[INSTERT FIGURE 1]}

Several non-financial Danish companies argue that the banks after the financial crisis have tightened their credit. Even companies with promising investment opportunities claim that they cannot obtain the necessary bank credit. It is quite possible that this is the overall situation, as the growth in lending in 2010 has declined dramatically to less than a half percentage.

During the booming years it was easy to get credit and the banks boosted their balances through aggressive lending, sometimes to dubious entrepreneurs with real estate projects. In Denmark, as in many other parts of the world, real estate prices soared and loans associated with real estate were effective devices to increase risky lending, but as long as the prices only went one way i.e. up, only very few financial institutions worried. Rapid growth is also associated with increased risk taking, as the credit quality may be weakened.

This means that customers who normally were ineligible to get housing credit e.g. for the down payment, received funding anyway. Therefore, there is evidence that the high level of lending growth may be one of the many causes of the financial crisis.

Figure 1 also reveals that the ratio between lending and borrowing was quite high in the years prior to the financial crisis. By leveraging this ratio, banks may have increased their liquidity risk and thereby the risk of going bankrupt. The average ratio prior and during the crisis was below the socalled "Supervisory Diamond", since the ratio was 1.15.

This ratio has been substantially reduced in 2010 as banks tried to reduce their lending and increase deposits in order to strengthen their liquidity. When the financial crisis was at its peak, several banks promised depositors high interest rates, such as 5 percent in order to attract funding 
from ordinary depositors. The ratio has dropped to 1.08, but it is still relatively high and will also in the coming years constitute a challenge for some Danish banks.

If one looks at the liquidity surplus, figure 1 shows a dramatic improvement in the liquidity conditions of Danish banks, as the number has increased from 120 to nearly 240. Again there are large deviations among the banks, but it is positive that the banks have improved their liquidity positions. This is especially important, as Denmark is one of the few countries where ordinary depositors have lost some of their savings i.e. not only have the banks shareholders lost their money, but depositors with more than 100.000 EUR in their bank account have also suffered liquidity reductions. This has made the funding situation difficult for Danish banks, as liquidity is crucial for any bank.

The exposure to large customers has been reduced dramatically in the last year which is positive since high exposure to large customers (in excess of 10 percent of the base capital) exposes a bank to serious risks. The reason is that insolvent customers and the bank may share a common negative financial destiny. In this scenario, a bank has to decide whether to realize a loss writing down the loan in case of an "objective indication of value decline" as the law mentions. This implies that the loan must be reduced to the net present value of the expected payments from a customer.

However, in some cases it actually makes sense not to write-off such loans too fast. To illustrate, if a large customer has borrowed a lot of money for real estate investments, the value of the houses in the case of a fire sale will be very low, hence a bank may have an interest in helping the customers through tough times expecting that real estate prices will increase in the coming years. This tradeoff must be made on a concrete basis, but it should be recognized that the choice may be rather difficult in practice, especially when there is a high degree of uncertainty about the health of the economy. Nevertheless, it is positive that the banks have reduced their sensitivity to large customers quite significantly in the last year compared to the period prior to the crisis. 
Total loan exposure to the real estate market was equal to 14 percent from 2005-2009 (it should be noted that not all banks disclose their real estate loan exposure). However, since it has not been possible to calculate the number for the year 2010, real estate exposure does enter the figure. Instead, the ratio of total loans to equity is displayed showing the degree of "leverage" in the years prior to the crisis, which is equal to 6.64 .

\section{Corporate governance characteristics in Danish banks}

The supervisory board consists of 7.5 persons on average. Figure 2 shows that there are more than two employee elected members on the supervisory boards. Another difference compared to the "pure" two- tier board system which prevails e.g. in Germany, is that the supervisory board in Denmark is not supposed to only monitor the board of executives or "inside" directors. The supervisory board is responsible for the overall strategy and has decision power in cases of extraordinary matters or in cases of great importance, such as large credit arrangements. Moreover, members of the supervisory board are entitled to comprise less than fifty percent of the company according to the Danish Company Act, but in practice "inside" directors are very seldom formally members of the supervisory board.

\section{[INSERT FIGURE 2]}

Figure 2 also documents the relatively small number of executive directors i.e. around 1.5, which is not surprising since the majority of Danish banks are relatively small.

According to the law, the maximum tenure period for board members is four years in which a board member must either be re-elected or dismissed. The Danish Company Act provides that any board member may be reelected annually, which is also recommended in the Corporate Governance Code. Figure 2 shows that the average tenure is close to three years. This might constitute a challenge as shareholders will not annually be able to hold board members accountable 
for any misconduct or incompetence. The number of external board positions for each board member is relatively limited, namely around 2.5 .

One may argue that it becomes a problem if board members have too many external board positions in other firms, since they might not have enough time to carry out their board tasks adequately. On the other hand, external board positions may be considered beneficial for a bank as members of the supervisory board are attractive to other firms where they can use their personal network in crisis situations or when a bank faces difficult challenges.

\section{[INSERT FIGURE 3]}

Figure 3 depicts selected corporate governance attributes of the Danish listed banks. It is striking to notice that the proportion of women is quite low i.e. just around 12 percent. The Danish financial sector has traditionally been dominated by men at the top management level, but the low proportion of female board members is not only restricted to the financial sector, see Rose (2007) for an analysis of board diversity and firm performance. The crucial issue here is not to deny this problem, but to discuss what measures are needed in order to increase this proportion. Some jurisdictions have quota laws such as Norway, Spain and France, but soft quota law still prevails in Denmark.

The market for corporate control has played a vital role in countries such as the US and the UK, but this is not the case in Denmark, in particular among Danish banks. The reason is that voting right and ownership ceilings are frequent among Danish banks.

Some have argued that these provisions in a bank's articles of incorporation provide executive management with too much power at the expense of the shareholders. Proponents of takeover defenses argue that such provisions protect the banks against powerful majority shareholders who seek to maximize their own utility at the expense of small minority shareholders. 
For instance, it may be difficult in practice for an executive credit director to reject a credit application from a controlling majority shareholder. Eventually, it becomes an empirical question if takeover defenses are beneficial or detrimental for a bank's performance.

During the financial crisis, Denmark also witnessed a public critique against executive pay in the financial sector. In particular, this was related to a specific bank failure (Roskilde Bank), where the CEO received huge benefits and stock options prior to the time the bank went into financial distress. As a result the bank was taken over by Finansiel Stabilitet. The CEO of Roskilde Bank received stock options of a value of 30 million DKK even though the bank shortly after collapsed due to excessive credit risk taking in combination with a weak supervisory board. Figure 4 shows that the yearly average bank director remuneration (not weighted) equals around 2.5 million DKK. However, this number may understate the actual salaries as it has not been possible to obtain information about all elements of the total remuneration package to all bank CEOs. Figure 4 also shows that the average board remuneration was much lower i.e. around 150.000 DKK. The key question is of course if such a relatively low level of board remuneration is sufficient to attract qualified board candidates. Thus, there is also a large potential personal downside risk if a board member is to be sued in court for negligence in the case that plaintiffs claim damages for their losses.

\section{[INSERT FIGURE 4]}

\section{Regression results}

Table 1 shows fixed effect regression estimates when lending growth serves as the dependent variable. The following models rely on data from 2005-10 and not 2010. The table should be read in the following way. Six different regression equations have been estimated numbered 1 to 6 . Each regression equation contains specific explanatory corporate governance variables e.g. in the first regression where LnRemuneration Boardmembers as well as LnRemuneration "Inside” Directors serve as explanatory variables. Specifically, the coefficients measure the impact of a percentage increase in these two variables on the dependent variable i.e. Lending growth. 
None of the explanatory variables are significantly different from zero. This is also the case for the other variables not displayed in the table such as, ownership or voting right ceilings. Surprisingly enough, it is difficult to find quantitative corporate governance measures that influence lending growth.

\section{[INSERT TABLE 1]}

On the other hand, in table 2 where the dependent variable, Lending/Deposits (funding) serves as the dependent variable, we observe a number of significant explanatory variables.

\section{[INSERT TABLE 2]}

Table 2 shows that larger banks i.e. measured by book assets have higher ratios and are therefore more exposed due to the inherent maturity mismatch. Interestingly enough, we observe that director remuneration does not significantly impact funding whereas board remuneration has a significantly positive impact on funding even though it is weakly significant. In practice, "inside" directors may influence the ratio of lending/deposits more than board members. This is important as there is a significant negative relationship between the number of "inside" directors and this ratio whereas this is the opposite regarding the number of board members where the ratio is positive. A possible interpretation is that a single director may increase lending in order to boost his own remuneration compared with a situation where there are two or three executive directors.

It is also remarkable that increasing the number of female board members results in increased funding risk. The result therefore seems to reject hypothesis H1:4, since it is a widespread belief that females are more risk averse than men. This result indicates the opposite although we need more risk indicators in order to make strong conclusions.

The number of shareholder elected board members, the total number of external board positions or the average number do not significantly influence a bank's funding and this is also the case regarding the other governance variables not shown in the table. 
[INSERT TABLE 3]

Table 3 displays the impact on large customers where one notices that increasing the number of executive directors may reduce the exposure to large customers. The coefficient is $-21,86$ which is strongly and significantly different from zero. This figure illustrates, that if the number of "inside" directors is increased by one person, exposure towards large customers is reduced by 21.86 .

Again this could indicate that more "Inside" directors reduce a bank's credit risk exposure. Table 3 also displays that there is a strong positive relationship between large customers and "inside" directors' remuneration. Large customers may increase lending, but there is a risk that a bank becomes too dependent on a few large customers. Moreover, increasing the number of board members results in significantly lower exposure to large customers, especially increasing the members elected at the general meeting. The number of female board members, external board positions on average, as well as bank size, does not have a significant impact, which is also the case with the other governance variables not shown here.

\section{[INSERT TABLE 4]}

Table 4 displays the results when liquidity surplus serves as the dependent variable. Table 4 shows that larger firms have higher liquidity ratios and are therefore considered as less risky. The lack of liquidity is crucial for any bank as a sudden lack of confidence by customers may result in bank runs, hence the presence and access to sufficient liquidity is vital. If director remuneration increases, table 4 shows that liquidity is decreased. This indicates that increased remuneration to "inside" directors does not always result in increased risk taking. Table 4 also displays that increasing the number of "inside" directors may lower the liquidity ratio. None of the other displayed variables have any significant influence, which is also the case for the governance variables not shown in the table.

[INSERT TABLE 5] 
Table 5 shows how the explanatory corporate governance variables influence the proportion of loans to real estate. Pooled OLS regression is used in table 5 since there are too many missing observations regarding real estate exposure to conduct a traditional panel data analysis.

There is a clear positive relationship between "inside" directors' remuneration and lending exposure to the real estate market, hence if "inside" directors are paid a higher total salary, the bank becomes more risk exposed. The opposite is the case if the number of executive directors is increased, as table 5 shows a significantly lower exposure to real estate lending.

Larger banks also have higher exposure to real estate lending compared to smaller banks. None of the other variables have any significant influence on the real estate exposure which is also the case for the other governance variables not shown in the table.

\section{The Danish Bailout Package and corporate governance}

The credit package only had a duration of three years. Since the Danish financial sector was still not sufficiently sound when the package expired, the government had to launch new initiatives for winding-up banks. Package No. 3 was the most comprehensive regulatory initiative, as it laid the groundwork for a unorthodox bankruptcy procedure for Danish banks.

Specifically, when a bank fails to meet the requirements by the expiration of the deadline, the bank shall declare to Finansiel Stabilitet whether it wishes to transfer its activities to Financial Stabilitet (for a more detailed description in English see memorandum from the Danish Ministry of Economic and Business Affairs). Otherwise, the normal bankruptcy regime for banks applies. Finansiel Stabilitet can establish a subsidiary bank (New Bank), which takes over the assets of the failed bank (Old Bank). New Bank purchases the assets in the Old Bank at realization value. The realization value is the value that the assets represent at immediate transaction, taking the distressed bank's situation into consideration. The realization value shall be settled in an order that additional losses with a high degree of certainty will not occur. 
The share of the claims from the unsubordinated liabilities, which is not transferred to New Bank, will maintain a legal status as unsubordinated liabilities against the Old Bank, according to normal insolvency order. Creditors not accepting the change of debtor, remain as creditors to the

Old Bank. The depositor's access to set-off will not be affected by the transfer of assets from the distressed bank to the subsidiary of Finansiel Stabilitet to the extent where depositors may only set- off liabilities if such liabilities are transferred to the subsidiary. More concretely, a depositor's net-deposit is covered up to EUR 100,000. Regular depositors with a net-deposit below this threshold will thus not be directly affected by the transfer to New Bank.

This initiative was followed by the stability package No. 4. It contained an extended dowry scheme in which banks were paid to acquire unhealthy banks from the state and Finansiel Stabilitet. Perhaps, more importantly, banks that merged would get their state loans prolonged to three years as well as the possibility to obtain an individual state guarantee when seeking to merge with another bank. It seems quite plausible that these initiatives were sound vehicles to avoid the destabilization of the entire financial system.

\section{[INSERT TABLE 6]}

Table 6 shows corporate governance determinants of state capital by Danish Banks. Specifically, table 6 displays the results from the logit regressions where each corporate governance variable has been included in each model. Logit (or alternatively Probit) models are used when the dependent variable is of binary nature. The data is based on average values over the period. The estimates show that it is difficult to identify any corporate governance variables that have a significant influence on the probability of obtaining state capital.

Table 6 documents that when the total number of board members and the members elected by the employees increase the likelihood declines. This is also the case when managerial remuneration increases. As a consequence, the results seem to support the formulated hypothesis H2. Thus, all equations have been re-estimated including size (LnAssets, but not shown in the table), but size is not significantly different from zero in any of equations. 
Moreover, it may be argued that the bailout variable is likely overdetermined, with several confounding factors at play. As illustrated in this article, the Danish experience mirrors the US experience, as financial institution bailouts during the crisis took place in sequential programs. Ideally, one would like to control for the political economy and law of bailouts. Big banks are more likely to receive bailouts; and big banks are, in addition to being more likely to have large boards, are also more likely to have higher paid CEOs. Only after the financial crisis i.e. in 2013 Denmark developed its own rules regarding the handling of systemically important financial institutions.

The issue of endogeneity is discussed frequently within applied econometrics and social science where the casual relationship between variables can be less intuitive. In other words, it may be difficult to distinguish between dependent and independent variables. The textbook solution entails the use of instruments i.e. variables that are correlated with the dependent variable but uncorrelated with the residuals. To illustrate, LnAssets may influence lending growth and vice versa. However, in practice, it is extremely difficult to find suitable instruments. Therefore, the article's results should be viewed with this caveat in mind.

\section{Conclusion}

This article has conducted an extensive analysis of the corporate governance structure of Danish listed banks in the years leading up to the financial crisis. The main purpose of this article has been to explore if weak corporate governance structures can be associated with excessive credit risk taking, which could help explain why so many Danish banks went into financial distress after the crisis.

This article cannot completely verify H1, but there is evidence that parts of the Danish banks corporate governance structures were insufficient. This is especially the case for directors remuneration which shows a strong relationship with the proportion to the real estate sector as well as to large customers. 
On the other hand, this article demonstrates that increasing the number of "inside" directors diminishes banks risk exposure, as more "inside" directors reduces the exposure to large customers as well as loans to the real estate sector. A possible explanation could be that more "inside" directors constitutes a more stable system with a higher degree of checks and balances. The policy implication is therefore that the FSA may consider introducing a requirement of at least two "inside" directors in banks executive boards.

The article also documents that the likelihood of receiving state credit capital is reduced when managerial remuneration increases, which is also the case if the number of board members increases.

The findings of the article offer a number of policy implications. First, the article has identified which corporate governance features are related to banks credit risk exposure. The new CRD 4 rules impose limits on the number of board positions that board members must occupy. This article does not find any significant link between banks credit risk exposure and the total number of board seats held by the supervisory board members. Instead, the article finds a relationship between credit risk exposure and Director Remuneration that could speak in favor of the new hard law restrictions on variable pay in the CRD rules.

The insights of the article contribute to the ongoing debate about corporate governance in the financial sector, including the choice between hard law and soft law financial regulation. The article has shown that even though there are some indications that the Danish corporate governance system in the years leading up to the crisis proved insufficient, the results also demonstrate that the analysis is complex and must be nuanced. Therefore, we may expect more research within this area in the coming years, including how to design financial regulation that could help protect the stability of the financial sector. 


\section{Acknowledgement}

I am very grateful to research assistant Eskild Johannsen for excellent and careful work with the data collection. I am also grateful for very useful comments from two anonymous referees.

\section{References}

Adams, Renee, Heitor Allmeida and Daniel Ferreira (2005) "Powerful CEOs and their impact on corporate performance”, Review of Financial Studies, 18: 1403-1432

Adams, R (2009). Governance and the financial crisis, In Steen Thomsen, Caspar Rose and Ole Risager (Eds.), Understanding the financial crisis: Investment, risk and governance, SimCorp.

Adams and Mehran (2012), Bank board structure and performance: Evidence for large bank holding companies, Journal of Financial Intermediation, 21; 243-267

Adams, Renee and Daniel Ferreira (2009), Women in the boardroom and their impact on governance and performance, Journal of Financial Economics, 94, 291-309

Aebi Vincent, Gabriele Sabato and Markus Schmid (2012), Risk management, corporate governance and bank performance, Journal of Banking and Finance, 36; 3213-3226

Ahrens, Thomas, Igor Filatotchev and Steen Thomsen (2011). The research frontier in corporate governance, Journal of Management and Governance, 15: 311-325

Bebchuk, Lucian A., K. J. Martijn Cremers and Urs C. Peye (2011), “The CEO pay slice”, Journal of Financial Economics, vol. 102, iss. 1: 199-221

Berger, Allen N., Thomas Kick and Klaus Schaeck (2012), Executive board composition and bank risk taking, Deutsche Bundesbank Working Paper No. 3.

Busta, Ilduara, Evis Sinani and Steen Thomsen (2014), Ownership concentration and market value of European Banks, Journal of Management and Governance, 18:159-183

The Danish FSA, see; https://www.finanstilsynet.dk/Finanstilsynet/Tal-og-fakta/Statistiknoegletal-analyser/Tilsynsdiamanten, regarding the Danish Supervision Diamond in English

Diamond, Douglas W. and Raghurram G. Rajan (2009), The credit crisis: Conjectures about causes and remedies, American Economic Review, 99, 606-610 
Erkens, David H., Mingyi Hung, and Pedro Matos (2012), Corporate Governance in the 2007-2008 financial crisis: Evidence from financial institutions worldwide, Journal of Corporate Finance, 18; $389-411$

Fahlenbrach, Rüdiger, and Rene Stulz (2011), Bank CEO incentives and the credit crisis, Journal of Financial Economics, 99; 11-26

Financial Times on AIG: http://www.ft.com/cms/s/o/7e2b6428-851a-11dd-b148oooo779fd18c.html\#axzz3XrhAhrIu

Gerald T. Garvey, Todd T. Milbourn, (2006) “Asymmetric benchmarking in compensation:Executives are rewarded for good luck but not penalized for bad", Journal of Financial Economics, 82: 197-225

Grossman, Sanford and Oliver Hart (1983), “An analysis of the principal agent problem”, Econometrica, 51: 7-45

Hall, Brian and Kevin Murphy (2003) “The trouble with stock options”, Journal of Economic Pespectives, 17: 49-70

Hideaki Sakawa, Keisuke Moriyama and Noaki Watanabel (2012), Relation between top executive compensation and corporate governance: Evidence from Japanse public disclosed data, Corporate Governance: An International Review, 20; 593-608

Himmelberg, Charles, Glenn Hubbard and Darius Palia (1999), "Understanding the determinants of managerial ownership and the link between ownership and performance”, Journal of Financial Economics, 53: 353-384

Holmstrom, Bengt (1979), "Moral hazard and observability”, Bell Journal of Economics, 10: 74-91

Hugh Grove, Lorenzo Patelli and Lisa M. Vicoravich (2011), Corporate governance and performance in the wake of the financial crisis: Evidence from US commercial banks, Corporate Governance: An International Review 19; 418-436

Ingley, Coral, Jens Mueller and Graeme Cocks (2011). The financial crisis, investor activists and corporate strategy: will this mean shareholders in the boardroom? Journal of Management and Governance, 15: 557-587 
Jie Cai and Anand M. Vijh, (2007) "Incentive Effects of Stock and Option Holdings of Target and Acquirer CEOs", Journal of Finance, vol. 62, N. 4: 1891-1933

Johnston, Jack, and John DiNardo (1997), Econometric methods, forth. ed. McGraw Hill

Kirkpatrick, Grant (2009), The corporate governance lessons from the financial crisis, Financial Market Trends, OECD

Laux, Volker (2012)”, Stock option vesting conditions, CEO turnover and myopic investment”, Journal of Financial Economics, 116: 513-526

Masulis W, Ronald, Cong Wang and Fei Xie, (2007) “Corporate governance and acquirer returns”, Journal of Finance, Vol. 62, No. 4: 1851-1889

MiFID II, see http://ec.europa.eu/finance/securities/isd/mifid2/index_en.htm

Morse, Adair, Vikram Nanda and Amit Seru (2011), “Are incentive contracts rigged by powerful CEOs?” Journal of Finance, 76: 1779-1821

Muller-Kahle, Maureen I. And Krista Lewellyn (2011), Did board configuration matter? The case of US subprime lenders, Corporate Governance: An International Review, 19:405-417

SEC Homepage: http://www.sec.gov/spotlight/dodd-frank.shtml

Shleifer, Andre and Robert Vishny (1997), “A survey of corporate governance”, Journal of Finance, Vol. 52, No. 2, 737-783

Shleifer, Andrei, and Robert Vishny, (2003), "Stock market driven acquisitions", Journal of Financial Economics 70: 295-311.

Viral V. Acharya, Kose John, Rangarajan and K. Sundaram (2000), "On the optimality of resetting executive stock options", Journal of Financial Economics, 57, 65-101

Rose, Caspar (2008), Employee appointed board members and corporate governance, European Business Organization Law Review, 9:215-235, 2008

Rose, Caspar (2007), Does Female Board Representation Influence Firm Performance? The Danish Evidence, Corporate Governance: An International Review, 2007, Vol. 15, No. 2: 404-413 
Rost, Katja and Margit Osterloh (2010), Opening the black box of the upper echelons: Drivers of poor information processing during the financial crisis, Corporate Governance: An International Review, 18; 212-233

Walker, Sir David, (2009), A review of corporate governance in the UK banks and the other financial industry entities, Final recommendations, November 26

Yin-Hua Yeh, Huimin Chung and Chih-Liang Liu (2011). Committee independence and financial performance during the 2007-08 credit crunch: Evidence from a multi-country study, Corporate Governance. An International Review, 16: 437-458

Yermack, D. (1996). Higher market valuation of companies with a small board of directors, Journal of Financial Economics 40; 185-211 


\section{Tables and figures:}

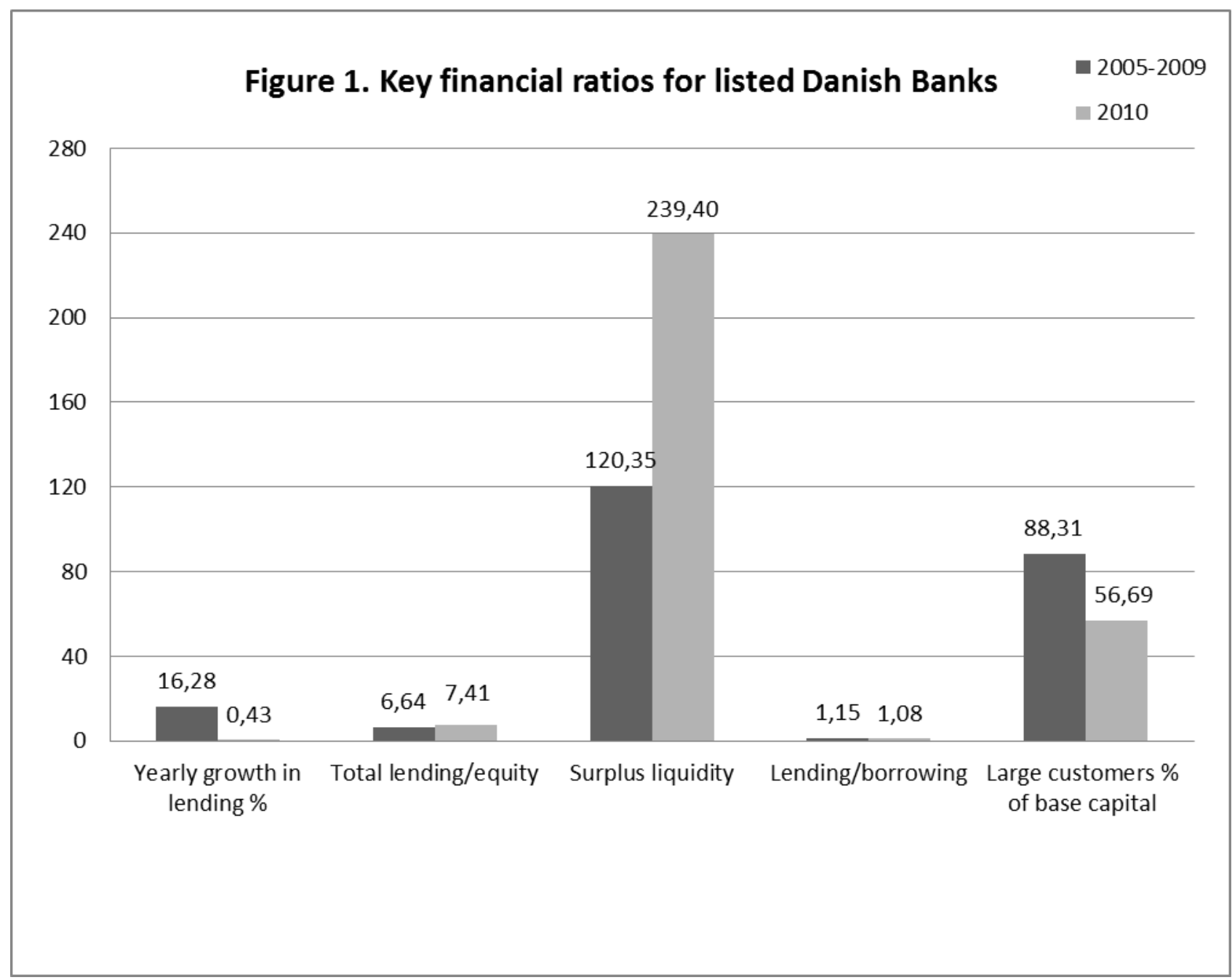

Source: Own calculations 


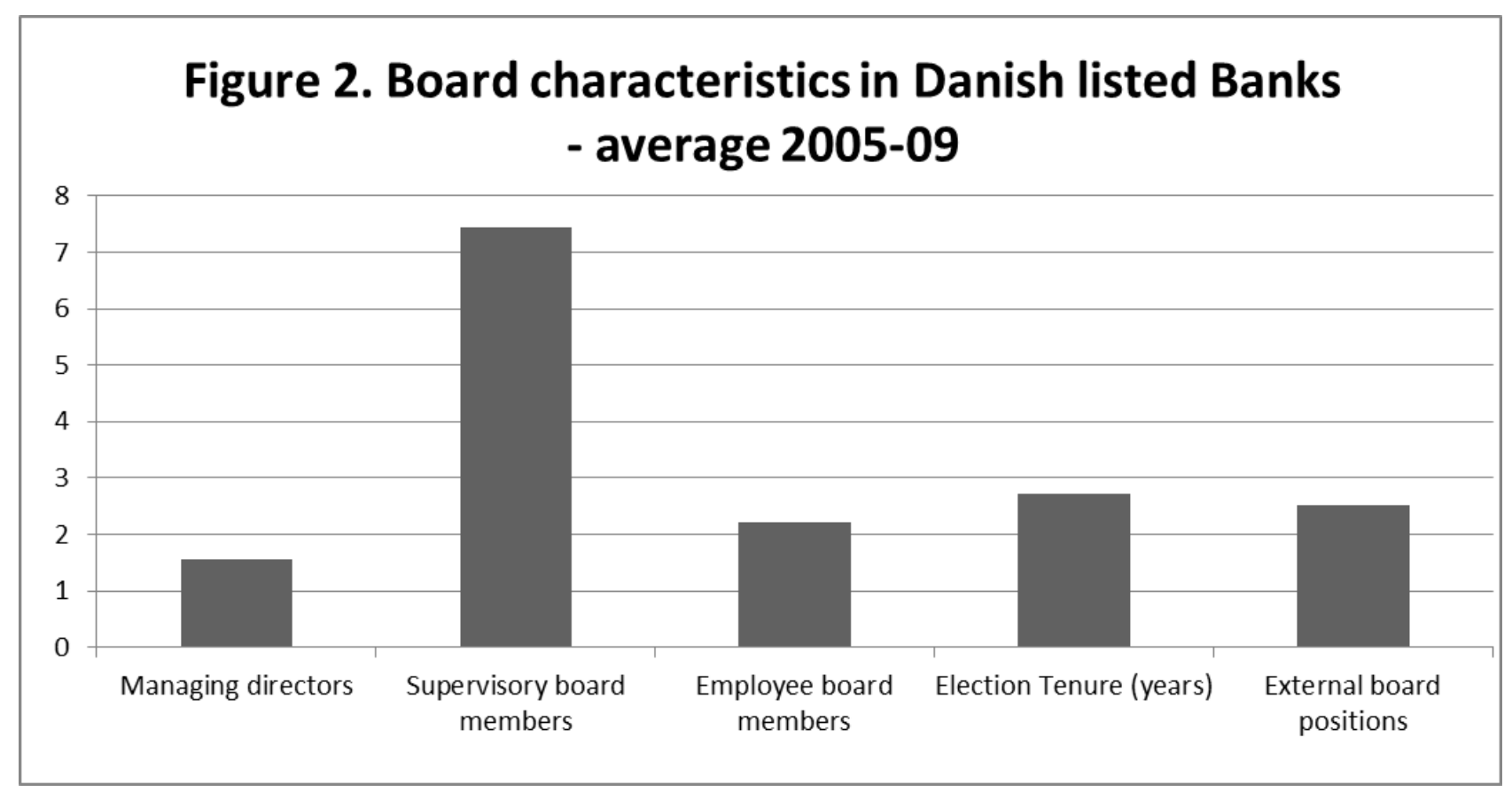

Source: Own calculations 
Figure 3. Selected corporate governance characterisics of Danish listed Banks in percentage

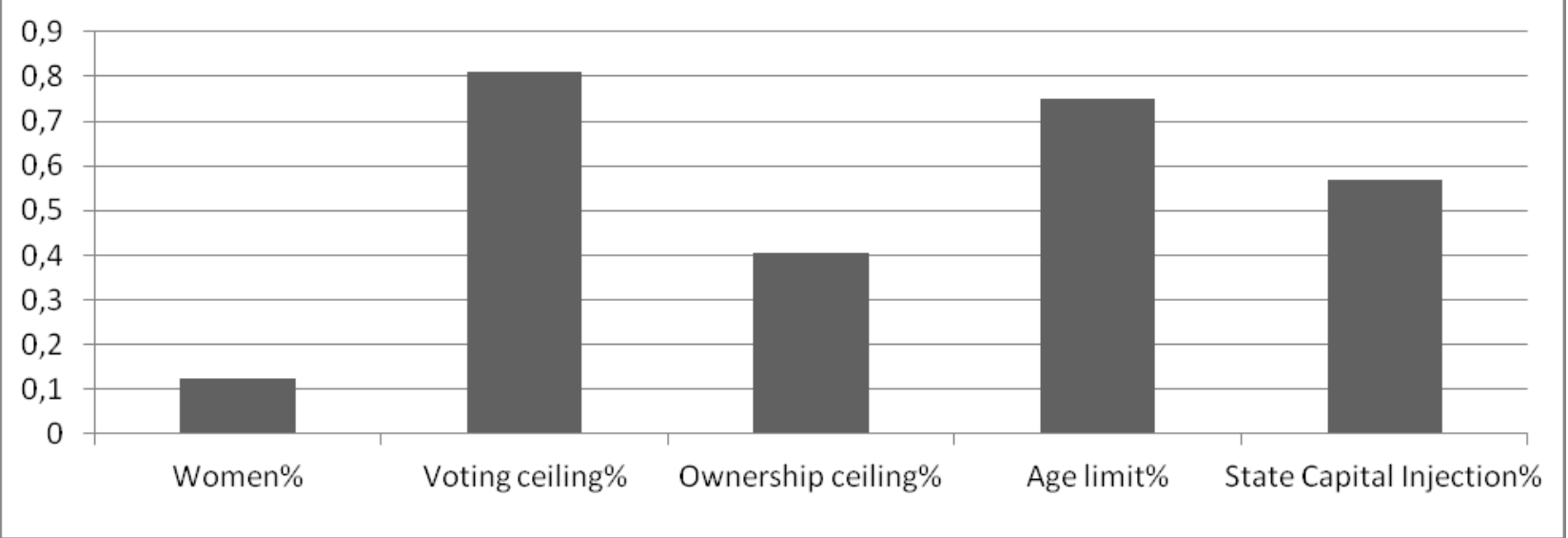

Source: Own calculations

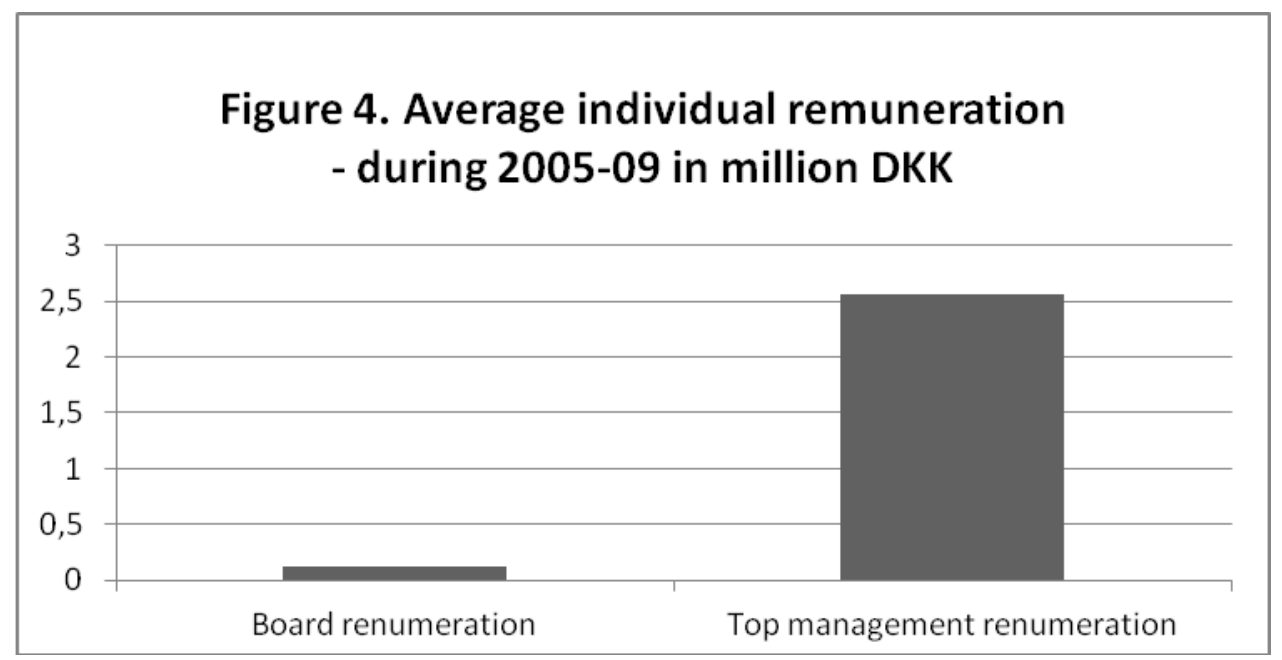

Source: Own calculations 
Figure 5. Correlation Matrix between financial variables. 2005-09

\begin{tabular}{|l|r|r|r|r|r|r|r|}
\hline & Lending $\Delta$ & Likvidity $\Delta$ & FundingRatio LargeCustomersRealEst.Loan\% & Assets BoardPay \\
\hline Lending $\Delta$ & 1,00 & & & & & & \\
\hline Likvidity $\Delta$ & $-0,52$ & 1,00 & & & & & \\
\hline FundingRatio & 0,29 & $-0,32$ & 1,00 & & & & \\
\hline LargeCustome & 0,37 & $-0,25$ & 0,45 & 1,00 & & \\
\hline RealEst.Loan\% & 0,15 & $-0,15$ & 0,59 & 0,62 & 1,00 & \\
\hline Assets & $-0,01$ & $-0,03$ & 0,10 & 0,05 & $-0,06$ & 1,00 & \\
\hline BoardPay & $-0,01$ & $-0,04$ & 0,25 & 0,15 & 0,05 & 0,77 & 1,00 \\
\hline DirectorPay & $-0,02$ & $-0,10$ & 0,34 & 0,38 & 0,34 & 0,45 & 0,63 \\
\hline
\end{tabular}

Figure 6. Correlation Matrix: Corporate Governance variables 2005-09

\begin{tabular}{|c|c|c|c|c|c|c|c|c|c|c|c|}
\hline \multirow[b]{2}{*}{ VotingCap } & \multicolumn{11}{|c|}{ VotingCapJwnerCapvoDirector"BoardsMe Female :mploMem 1 ABdumm reholderMBpositions v.BpositiorElecPeriod } \\
\hline & 1,00 & & & & & & & & & & \\
\hline OwnerCap & 0,29 & 1,00 & & & & & & & & & \\
\hline NoDirectors & $-0,17$ & $-0,11$ & 1,00 & & & & & & & & \\
\hline NoBoardsMem & $-0,20$ & 0,10 & 0,61 & 1,00 & & & & & & & \\
\hline Female & $-0,26$ & 0,03 & 0,40 & 0,75 & 1,00 & & & & & & \\
\hline EmploMem & $-0,05$ & 0,11 & 0,54 & 0,84 & 0,68 & 1,00 & & & & & \\
\hline MABdummy & 0,09 & 0,04 & 0,23 & 0,36 & 0,25 & 0,73 & 1,00 & & & & \\
\hline Shareh.Mem & $-0,25$ & 0,03 & 0,53 & 0,90 & 0,69 & 0,53 & $-0,01$ & 1,00 & & & \\
\hline Bpositions & $-0,28$ & 0,00 & 0,68 & 0,68 & 0,54 & 0,55 & 0,27 & 0,61 & 1,00 & & \\
\hline Av.Bpositions & $-0,23$ & $-0,03$ & 0,51 & 0,35 & 0,28 & 0,34 & 0,26 & 0,24 & 0,89 & 1,00 & \\
\hline ElecPeriod & 0,03 & 0,03 & $-0,26$ & $-0,19$ & $-0,37$ & $-0,13$ & $-0,11$ & $-0,18$ & $-0,34$ & $-0,28$ & 1,00 \\
\hline AgeLimit & $-0,11$ & $-0,03$ & 0,14 & 0,28 & 0,18 & 0,36 & 0,41 & 0,10 & 0,25 & 0,22 & $-0,39$ \\
\hline
\end{tabular}


Figure 7. Descriptive statistics for all the variables: 2005-09

\begin{tabular}{|lrrrrrr|}
\hline \multicolumn{7}{c}{ FIGURE 7. Simple Statistics: Pooled observations } \\
\hline Variable & N & Mean & Std Dev & Sum & Minimum & Maximum \\
\hline Lending & 182 & 16.82308 & 18.22572 & 3062 & -17.90000 & 88.50000 \\
Likvidity & 183 & 119.16667 & 69.47750 & 21808 & 3.90000 & 342.40000 \\
FundingRatio & 185 & 1.12737 & 0.36337 & 208.56400 & 0 & 2.00000 \\
LargeCustomers & 183 & 90.59180 & 70.20094 & 16578 & 0 & 416.30000 \\
RealEst.Loan & 167 & 13.81982 & 8.23860 & 2308 & 2.00000 & 42.40000 \\
Assets & 182 & 75450 & 358400 & 13731836 & 18.62100 & 2678868 \\
BoardPay & 177 & 0.12704 & 0.10111 & 22.48619 & 0.02822 & 0.60000 \\
DirectorPay & 175 & 2.69730 & 1.50101 & 472.02775 & 1.00500 & 11.66800 \\
VotingCap & 180 & 0.80556 & 0.39688 & 145.00000 & 0 & 1.00000 \\
OwnerCap & 175 & 0.42857 & 0.49629 & 75.00000 & 0 & 1.00000 \\
NoDirectors & 175 & 1.57714 & 0.94294 & 276.00000 & 1.00000 & 5.00000 \\
NoBoardsMem & 178 & 7.48315 & 2.25550 & 1332 & 4.00000 & 15.00000 \\
Female & 175 & 1.04571 & 1.17843 & 183.00000 & 0 & 6.00000 \\
EmploMem & 174 & 2.24713 & 1.11835 & 391.00000 & 0 & 5.00000 \\
MABdummy & 175 & 0.88000 & 0.32589 & 154.00000 & 0 & 1.00000 \\
ShareholderMem & 179 & 5.30726 & 1.42233 & 950.00000 & 3.00000 & 10.00000 \\
Bpositions & 169 & 20.27219 & 17.15710 & 3426 & 1.00000 & 86.00000 \\
Av.Bpositions & 179 & 3.42456 & 2.79820 & 612.99643 & 0 & 15.75000 \\
ElecPeriod & 173 & 2.69364 & 1.10170 & 466.00000 & 1.00000 & 4.00000 \\
AgeLimit & 178 & 0.75281 & 0.43260 & 134.00000 & 0 & 1.00000 \\
\hline
\end{tabular}




\begin{tabular}{|c|c|c|c|c|c|c|}
\hline Explanatory variables: & 1. & 2. & 3. & 4. & 5. & 6. \\
\hline Constant & $\begin{array}{r}-83,24 \\
(0,51)\end{array}$ & & & & & \\
\hline LnAssets & $\begin{array}{l}6.82 \\
(0,47)\end{array}$ & & & & & \\
\hline LnRemuneration Boardmembers & $\begin{array}{l}7,62 \\
(0,33)\end{array}$ & & & & & \\
\hline LnRemuneration Directors & $\begin{array}{l}-3,81 \\
(0,44)\end{array}$ & & & & & \\
\hline № “Inside" Directors & & $\begin{array}{l}1,66 \\
(0,56)\end{array}$ & & & & \\
\hline № “Outside“ Board members & & $\begin{array}{l}-2,81 \\
(0,22)\end{array}$ & & & & \\
\hline № Shareholder elected board membe & & & $\begin{array}{l}-3,30 \\
(0,14)\end{array}$ & & & \\
\hline № Female board members & & & & $\begin{array}{l}-0,52 \\
(0,83)\end{array}$ & & \\
\hline Total external board positions & & & & & $\begin{array}{l}-0,01 \\
(0,93)\end{array}$ & \\
\hline External board positions on average & & & & & & $\begin{array}{l}3,43 \\
(0,61)\end{array}$ \\
\hline $\mathrm{R}^{2}$ & 0,06 & 0,06 & 0,06 & 0,07 & 0,07 & 0,07 \\
\hline F-value for no fixed effect & 6,18 & 6,11 & 6,27 & 6,14 & 6,21 & 6,31 \\
\hline
\end{tabular}

p-values in the parentheses 
Table 2. Fixed effect estimates when FUNDING (lending/deposits) serves as dependent variable: Years 2005-09

\begin{tabular}{|c|c|c|c|c|c|c|}
\hline Explanatory variables: & 1. & 2. & 3 . & 4. & 5. & 6. \\
\hline \multirow[t]{2}{*}{ Constant } & $-19,2^{*}$ & $-3,60^{*}$ & $-9,11$ & $-24,94$ & $-57,68$ & $-53,52$ \\
\hline & $(0,10)$ & $(0,06)$ & $(0,91)$ & $(0,75)$ & $(0,46)$ & $(0,49)$ \\
\hline \multirow[t]{2}{*}{ LnAssets } & $23,00^{*}$ & $* * * 18,00^{* *}$ & ${ }^{*} 15,64 *$ & $19,69^{* *}$ & & $23,27^{* *}$ \\
\hline & $(0,01)$ & $(0,05)$ & $(0,09)$ & $(0,02)$ & & $(0,01)$ \\
\hline \multirow[t]{2}{*}{ LnRemuneration Boardmembers } & $0,14^{*}$ & & & & & \\
\hline & $(0,06)$ & & & & & \\
\hline \multirow[t]{2}{*}{ LnRemuneration Directors } & $-0,02$ & & & & & \\
\hline & $(0,73)$ & & & & & \\
\hline \multirow[t]{2}{*}{ № "Inside" Directors } & & $-0,06^{* * *}$ & & & & \\
\hline & & $(0,03)$ & & & & \\
\hline \multirow[t]{2}{*}{ № “External” Board members } & & $0,05^{* *}$ & & & & \\
\hline & & $(0,01)$ & & & & \\
\hline \multirow[t]{2}{*}{ № Shareholder elected board member } & & & 4,62 & & & \\
\hline & & & $(0,03)$ & & & \\
\hline \multirow[t]{2}{*}{ № Female board members } & & & & $5,31^{* *}$ & & \\
\hline & & & & $(0,02)$ & & \\
\hline \multirow[t]{2}{*}{ Total external board positions } & & & & & $-0,01$ & \\
\hline & & & & & $(0,96)$ & \\
\hline \multirow[t]{2}{*}{ External board positions on average } & & & & & & $-1,17$ \\
\hline & & & & & & $(0,14)$ \\
\hline $\mathrm{R}^{2}$ & 0,09 & 0,09 & 0,09 & 0,09 & 0,09 & 0,09 \\
\hline F-value for no fixed effect & 31,40 & 38,46 & 36,87 & 36,94 & 35,07 & 35,59 \\
\hline
\end{tabular}

p-values in the parentheses where $* * * * * * * *$ denote 10,5 and $10 \%$ significance levels 


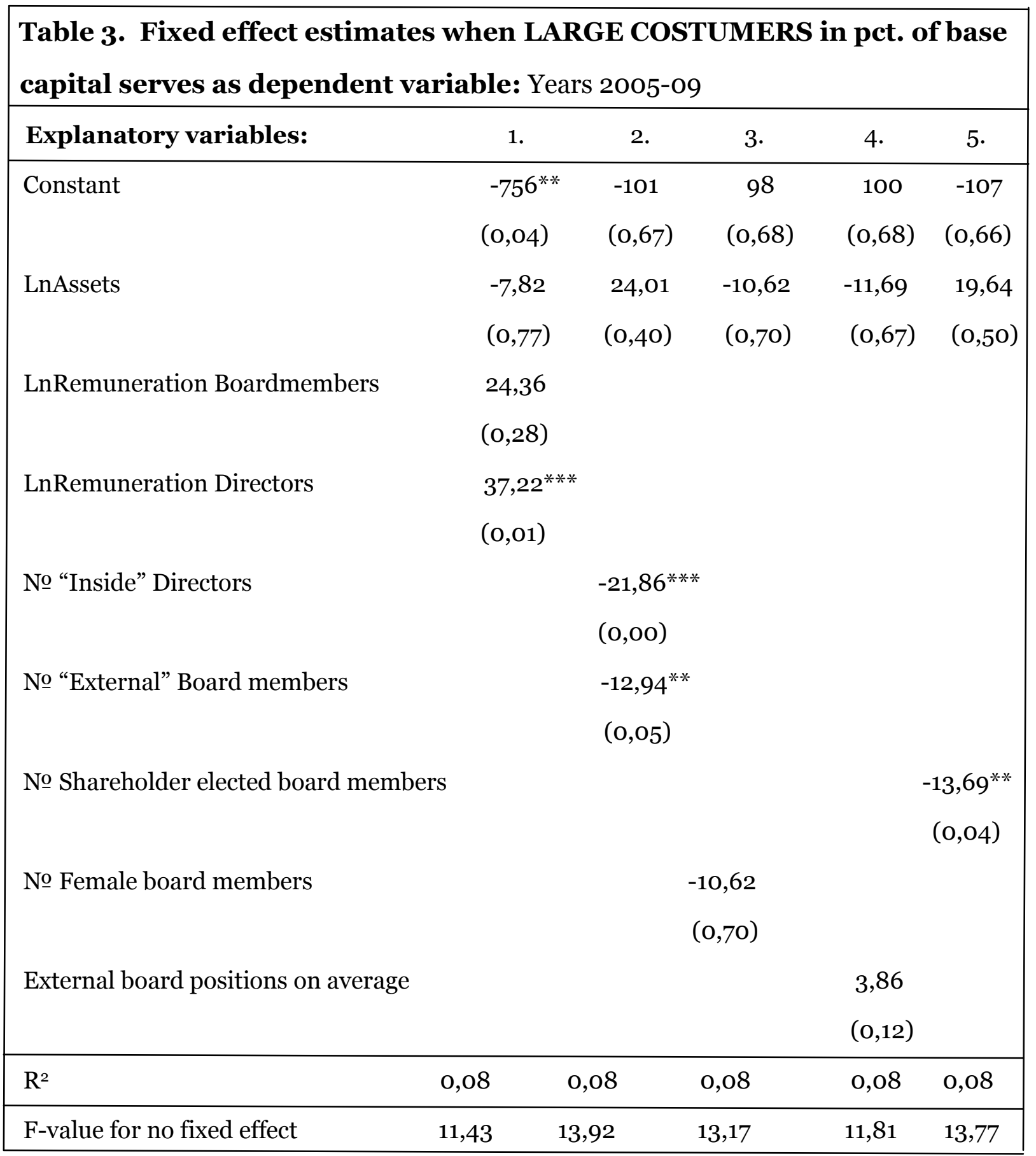

p-values in parentheses where ${ }^{*},{ }^{* *},{ }^{* * *}$ denote 10,5 and $10 \%$ significance levels 


\begin{tabular}{|c|c|c|c|c|c|}
\hline Explanatory variables: & 1. & 2. & 3. & 4. & 5 . \\
\hline Constant & $\begin{array}{l}-1078 * * * \\
(0,03)\end{array}$ & $\begin{array}{l}-1165^{* * *} \\
(0,00)\end{array}$ & $\begin{array}{l}-1077^{* * *} \\
(0,00)\end{array}$ & $\begin{array}{l}1082^{* * *} \\
(0,00)\end{array}$ & $\begin{array}{c}-1208^{* * *} \\
(0,00)\end{array}$ \\
\hline LnAssets & $\begin{array}{l}135,70^{* * *} \\
(0,00)\end{array}$ & $\begin{array}{l}161,74^{* * *} \\
(0,00)\end{array}$ & $\begin{array}{l}145,2 \\
(0,00)\end{array}$ & $\begin{array}{l}147,66 \\
(0,00)\end{array}$ & $\begin{array}{l}161,14^{* *} \\
(0,00)\end{array}$ \\
\hline LnRemuneration Boardmembers & $\begin{array}{l}-39,71 \\
(0,19)\end{array}$ & & & & \\
\hline LnRemuneration Directors & $\begin{array}{l}37,35^{* * *} \\
(0,04)\end{array}$ & & & & \\
\hline № “Inside" Directors & & $\begin{array}{l}-24,29^{* * *} \\
(0,03)\end{array}$ & & & \\
\hline № “Outside” Board members & & $\begin{array}{l}-5,09 \\
(0,58)\end{array}$ & & & \\
\hline № Shareholder elected board membe & & & & $\begin{array}{l}-3,76 \\
(0,66)\end{array}$ & \\
\hline № Female board members & & $\begin{array}{l}-8,41 \\
(0,40)\end{array}$ & $\begin{array}{l}-5,02 \\
(0,60)\end{array}$ & & \\
\hline External board positions on average & & & & & $\begin{array}{l}-3,03 \\
(0,38)\end{array}$ \\
\hline $\mathrm{R}^{2}$ & 0,07 & 0,07 & 0,06 & 0,06 & 0,06 \\
\hline F-value for no fixed effect & 6,01 & 5,96 & 5,79 & 5,72 & 5,97 \\
\hline
\end{tabular}

p-values in parentheses where ${ }^{*},{ }^{* *},{ }^{* * *}$ denote 10,5 and $10 \%$ significance levels 


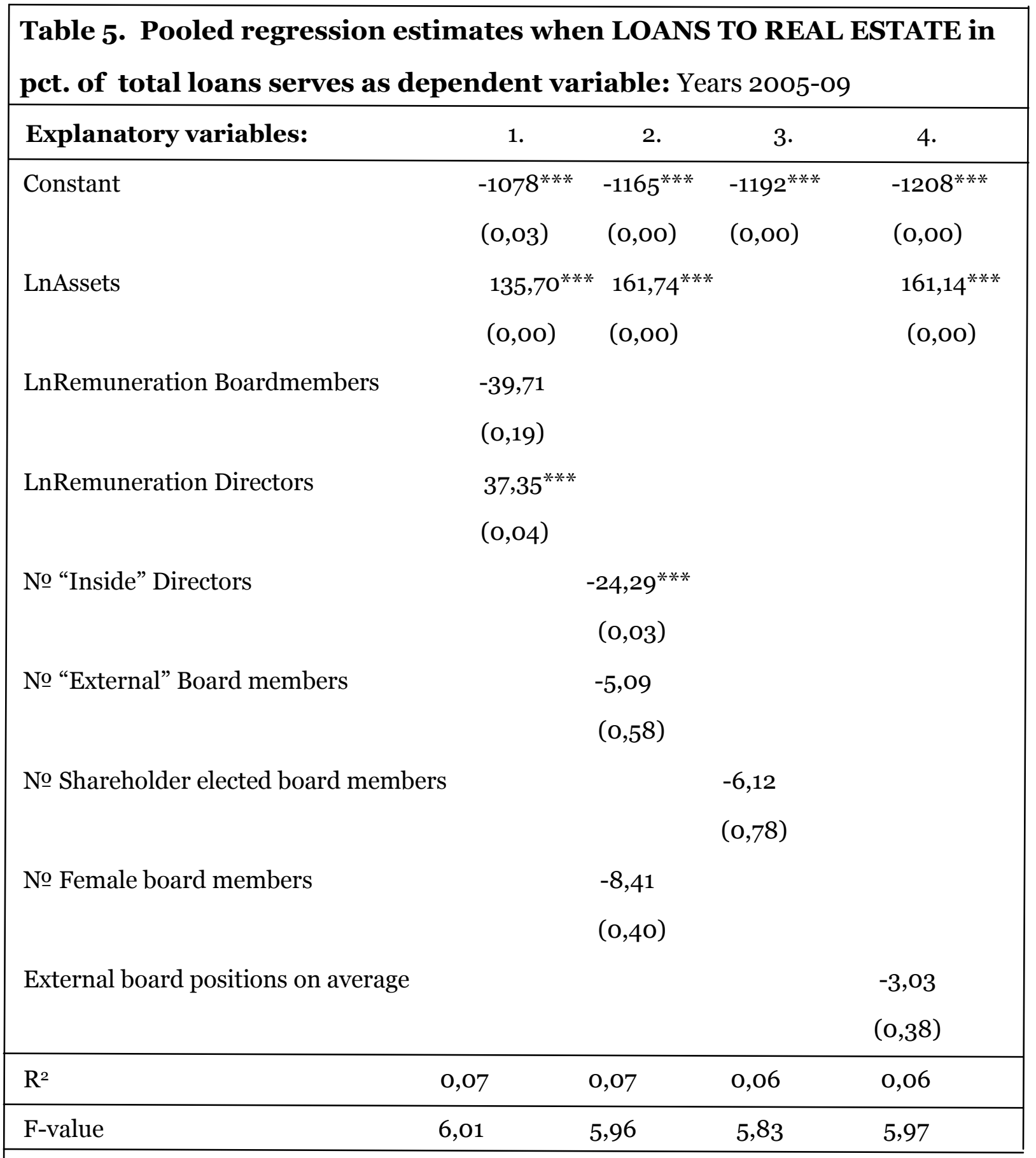

No. of observations

p-values in parentheses where ${ }^{*},{ }^{*},{ }^{* * *}$ denote 10,5 and $10 \%$ significance levels 


\section{Table 6 Logit regression of the likelihood of obtaining state capital from the credit bailout package or "Bank package II". Years 2005-09}

The dependent variable is in all estimated equations the likelihood of obtaining hybrid core capital i.e. $P_{z}$ vs. not obtaining such capital i.e. $\left(1-P_{z}\right)$ : The table shows each of the explanatory variables influence on the odds ratio. $\mathrm{N}=35$ observations based on average values over the period.

Test of significance is based on the Likelihood ratio with one degree of freedom that follows a chi square distribution, where $\left.{ }^{*}\right),{ }^{* *}$ ) and $)^{* * *}$ denote significance levels of 10,5 and 1 percent respectively, which are highlighted with bold.

\begin{tabular}{|c|c|c|c|c|c|}
\hline Explanatory variable: & Constant & Coef. & td. error & Odds ratio & 95\%conf. interval \\
\hline Remuneration directors & 0,988 & $-0,509^{*}$ & 0,332 & 0,601 & $0,313-1,151$ \\
\hline Remuneration board members & 0,471 & $-6,296$ & 5,434 & $0,002<$ & $<0,001-77,904$ \\
\hline № of "inside" directors & 0,363 & $-0,418$ & 0,429 & 0,659 & $0,284-1,528$ \\
\hline № of "external” board member & 2,071 & $-\mathbf{0}, \mathbf{3 2 2}^{*}$ & 0,199 & $\mathbf{0 , 7 2 5}$ & $0,491-1,069$ \\
\hline № Female board members & $-0,390$ & 0,953 & 3,248 & 2,539 & $0,004-\infty$ \\
\hline № Employee board members & 1,211 & $-0,711 *$ & 0,382 & 0,491 & $0,233-1,036$ \\
\hline № Shareholder elec. members & 0,946 & $-0,232$ & 0,270 & 0,793 & $0,467-1,346$ \\
\hline № Total board positions held & 0,310 & $-0,030$ & 0,024 & 0,971 & $0,926-1,018$ \\
\hline Specified election period & $-0,602$ & 0,116 & 0,316 & 1,123 & $0,605-2,084$ \\
\hline Age limit in the board & 0,223 & $-0,598$ & 0,777 & 0,550 & $0,120-2,521$ \\
\hline № of board positions average & 0,224 & $-0,200$ & 0,222 & 0,818 & $0,530-1,264$ \\
\hline Voting ceiling & 0,288 & $-0,693$ & 0,850 & 0,500 & $0,095-2,645$ \\
\hline Ownership ceiling & 0,000 & $-0,693$ & 0,694 & 0,500 & $0,128-1,949$ \\
\hline
\end{tabular}


